\title{
THE THEISTIC ARGUMENT FROM BEAUTY: A PHILONIAN CRITIQUE
}

\author{
BRIAN RIBEIRO \\ University of Tennessee at Chattanooga
}

\begin{abstract}
In this paper I consider an understudied form of the design argument which focuses on the beauty of the natural world and which argues, on that basis, that the world requires a divine Artist in order to explain its beauty. Against this view, one might raise a question concerning the beauty of, and in, this divine Artist. What explains the divine beauty? This kind of explanatory regress objection is exactly like that used by Philo in Hume's Dialogues to undercut standard versions of the design argument focused on the orderliness of the world. Here I argue that Philo's explanatory regress objection likewise significantly undercuts versions of the design argument focusing on the beauty of the world.
\end{abstract}

Conceived in a broad and intuitive way, the teleological argument (or, the design argument) holds that, given the ordered beauty of the world, its delicate arrangement of parts, and its general suitability as a habitation for humans, we can legitimately infer that our world is the work of some supernatural Designer. Historically speaking, presentations of the design argument have tended to focus our attention on the orderliness of the world (i.e., its being subject to natural laws which do not change, and so on). In ancient philosophical theology, this orderliness of the world was construed along the lines of organic models: The world is like an animal body, with an organic unity. In modern times, the theist's analogy has generally turned away from the organic model of animal bodies toward the model of complicated mechanisms: 'Look round the world, Cleanthes says in Hume's Dialogues, 'Contemplate the whole and every part of it: You will find it to be nothing but one great machine, subdivided into an infinite number of lesser machines, which again admit of subdivisions to 
a degree beyond what human senses and faculties can trace and explain.' Each of these different versions of the design argument looks from the world's orderliness to the need for a divine Designer to order it. ${ }^{2}$

But the design argument can also be presented in another, less common version which focuses its attention on the world's beauty and argues that natural beauty is itself a clear indication of the world's having been the product of conscious intention and design. To a very rough first approximation, if nature itself is beautiful like art, and if art requires an artist to make it beautiful, then perhaps nature itself needs an Artist. Call that the theistic argument from beauty. This beauty-based variant of the design argument has been defended by a number of philosophical theologians over the last 100 years or so. F. R. Tennant, Peter Forrest, Mark Wynn, and Richard Swinburne have all defended various versions of it. ${ }^{3}$ For example, Forrest claims that if he had to choose one feature of the universe that most clearly supports theism, it would have to be the beauty of things rather than the suitability of the universe for life. ${ }^{4}$ Explaining and elaborating this thought of his, Forrest insists that the argument from beauty has four distinct advantages over the usual design arguments:

The first is that [beauty] is harder to understand in naturalistic terms than is the suitability of the universe for life. The second is that ... beauty is best understood as the result of divine generosity, and like all the best gifts, its enjoyment is an end, not a means. This supports belief in anthropic rather than ananthropic theism. The third is that a sense of the beauty of creation acts as a counterweight to the emotional impact of suffering and malice, which, as I concede, provide prima facie grounds for atheism even after the undermining of all articulate formulations of the argument from evil. Finally, [the fourth is that] the theocentric understanding of beauty results in the emotional responses of both awe and gratitude, which is important because religious faith is widely granted to involve the emotions as well as the intellect. ${ }^{5}$

\footnotetext{
${ }^{1}$ Hume (1998: 15).

${ }^{2}$ Wynn notes this historical shift from organic to mechanistic analogies and provides references to several ancient and modern examples (1999: 11-13).

3 See Tennant (1930: 89-93); Forrest (1996: 38-41, 133-135); Wynn (1999), esp. Chapter 1 ('Providence and Beauty'); and Swinburne (2004: 121-122, 188-191). Wynn (1999) is far and away the most developed account of the argument and, as such, will receive proportionately more attention in my discussion.

${ }^{4}$ Forrest (1996: 39, my emphasis).

${ }^{5}$ Forrest (1996: 39).
} 
Thus, we seem to have a prima facie case for thinking that the argument from beauty deserves more careful consideration than it has generally received. If Forrest is correct, the argument from beauty may even be stronger than the standard design arguments that focus on orderliness.

However, in this paper I will be arguing that the theistic argument from beauty can be significantly weakened, and perhaps even outright defeated, by a form of objection which has also been applied to the usual design arguments. That objection is one I will be calling Philo's explanatory regress objection, and it is developed by Hume (through the character of Philo) in Part IV of the Dialogues. ${ }^{6}$ Thankfully, at least one of the recent defenders of the argument from beauty - Wynn (1999) has tried to directly address this explanatory regress objection, so we can consider his reply in developing the objection. In short, I will be arguing that Philo's explanatory regress objection is forceful and that Wynn's reply to it is inadequate - leaving Philo's objection standing and the theistic argument from beauty in serious trouble. ${ }^{7}$

\section{THE THEISTIC ARGUMENT FROM BEAUTY: AN INTRODUCTION}

In presenting and defending the argument from beauty F. R. Tennant has claimed that the world itself is 'saturat[ed]' with natural beauty. Such widespread natural beauty, Tennant argues, is relatively unlikely to have emerged without being brought about by artistic intentions. After all, in the human case, our works are rarely beautiful unless they are consciously designed with that end in mind. ${ }^{8}$ But if such widespread natural beauty really is 'relatively unlikely to obtain in the absence of artistic intent', then

\footnotetext{
${ }^{6}$ See esp. Hume (1998: 30-33). See also Hume (1998: 42-43 and 55-56).

${ }^{7}$ I should note, before moving on, that some philosophers have tried to connect (i) worldly beauty to (ii) a theistic belief, but without construing the connection between (i) and (ii) argumentatively (i.e., without treating the theistic belief in question as the conclusion of an inference). For a famous contemporary example of this non-inferential approach, one specifically drawing our attention to various cases of worldly beauty, see Plantinga (1981: 46-47); (1983: 18, 80-82); and (2000: 170-177). For a possible ancient version of the non-inferential approach, see Plato's discussion in the Symposium (esp. the 'ladder of love'/'ascent' passage [210a-212a]), along with further relevant discussion in the Phaedrus. (However, cf. Plato's Timaeus, where the treatment of worldly beauty appears to be more argumentatively-focused and natural-theological.) In any case, herein I will be focusing exclusively on the claim that worldly beauty can be put to use in developing an argument in the tradition of natural theology.

8 Tennant (1930: 91-92). Wynn provides a helpful analysis of Tennant's argument (1999: 16-20).
} 
that suggests that the world itself is (at least probably) the product of artistic intent. ${ }^{9}$

In my view, this argument is at its strongest when the focus is on the beauty of non-human nature, so I believe Tennant offers us an excellent starting point. Moreover, as Wynn has noted, recent empirical work on human reactions to natural beauty strongly suggests that human attraction to many kinds of natural landscapes is cross-cultural and stable. ${ }^{10}$ Moreover, while our appreciation of human artistic products (e.g., the masterworks of Shakespeare, Bach, or Picasso), ${ }^{11}$ or of the beauty of the human form, ${ }^{12}$ seems possible (and perhaps even relatively easy) to explain in naturalistic terms, our aesthetic appreciation of the wonders of non-human nature - the freshly fallen snow, or the jagged mountain tops, or the grasses waving in the wind - seems somewhat harder to explain naturalistically. ${ }^{13}$ Of course, some naturalistic explanations of our aesthetic appreciation of natural scenes have been proposed, such as E. O. Wilson's 'biophilia' hypothesis, which proposes that humans may have a partially genetic predisposition, acquired through evolutionary selection, to (aesthetically) prefer certain natural environments. ${ }^{14}$ Defenders of the argument from beauty have, therefore, spent some time trying to address the objection that naturalistic explanations of the world's beauty (to humans) can be found and hence theistic explanations are not needed. ${ }^{15}$

However, even if the argument from beauty can be defended against objections arguing for competitor naturalistic explanations of our human appreciation of worldly beauty, and even if the argument from beauty can be defended against objections focusing on whether beauty is objective or merely a subjective phenomenon, ${ }^{16}$ the argument's defenders will

9 See Wynn (1999: 21) for the quoted phrase.

${ }^{10}$ See, e.g., the survey of available research in Ulrich (1993), cited and discussed by Wynn (1998: 24ff).

${ }^{11}$ Richard Dawkins addresses (and critiques) the argument from beauty based on great works of art. See Dawkins (2008: 110-112). However, Dawkins does not consider either the beauty of the human form or, more importantly, the beauty of non-human nature in his discussion.

${ }^{12}$ See Forrest (1996: 134 n.15, 135).

13 Tennant (1930: 92-93).

${ }^{14}$ See Wilson (1984); see also Kellert and Wilson (1993).

${ }^{15}$ Wynn (1999: 26-35).

${ }^{16}$ This is a disputed issue among the defenders of the argument. Some, like Tennant, see no significant problem for the argument if beauty turns out to be subjective 
still have a problem: Supposing beauty to be a real feature of the world and supposing it to have a divine origin in the beauty of, and in, God's mind, what then explains that divine beauty? If beauty truly is such that it rarely emerges in the absence of artistic intent, then must we hypothesize an artistic Super-God to put the beauty into God? And, if so, must we hypothesize a Super-Super-God to put the beauty into Super-God, and so on ad infinitum? Here we see the worry behind Philo's explanatory regress objection, to which we can now turn our attention.

\section{PHILO'S EXPLANATORY REGRESS OBJECTION}

Let's start with the Indian philosopher mentioned by Locke in several passages of his Essay Concerning Human Understanding. ${ }^{17}$ If the world needs to be supported by resting on the back of an elephant, what supports the elephant? If you say the elephant is resting on the back of a mighty tortoise, then what supports the tortoise? One makes no real progress in addressing a question ('What supports X?') if the same question can be seen to simply re-emerge at the next level in the proposed explanation. One finds instead that, to avoid an infinite regress, something must be a 'brute' support, not supported by anything else.

Now consider a standard design argument focused on the world's orderliness. That kind of argument holds that since the world is so orderly, its order requires an explanation. If we make that demand into a general principle we get something like this: Things of great intricacy and complexity require an explanation and cannot be accepted as 'brute' inexplicable facts. ${ }^{18}$ But then what about the orderly divine mind that brings order to our world? Mustn't that divine mind be at least as complex as the world? Indeed, one would think it must be much more complex. But then, given our principle, the divine mind itself would require an explanation. If, faced with this worry, the theist proposes to

(1930: 89-90); others, like Swinburne, hold that the argument may need 'an objectivist understanding of the aesthetic value of the universe, in order to have significant strength' (2004: 191). For present purposes, I propose to leave the issue unresolved.

17 See John Locke, An Essay Concerning Human Understanding, II.xiii.19 and also II.xxiii.2. Hume alludes to the same story in Dialogues Part IV. See Hume (1998: 31). (N.B.: This edition of Hume's Dialogues, edited by Popkin, offers an incorrect reference to Locke's Essay II.xiii.2 [see p. 31, note 13], but that reference should read either II.xiii.19 or II.xxiii.2.)

${ }^{18}$ Notice that this principle is actually much weaker (and so more defensible) than a standard version of the principle of sufficient reason. 
treat the order of the divine mind as a 'brute' inexplicable fact, ${ }^{19}$ why can't the critic simply suggest (with equal justification) that the world itself may have that status? The point is that everyone - theists and non-theists alike - must accept some 'brute' inexplicable fact - or else accept an explanatory regress ad infinitum. In contrast, the theist had seemed to suggest, in presenting the design argument, that the design argument helps to remove some mystery that had puzzled us, but in fact the design argument only pushes the mystery (if there is one) back one step. Moreover, given that everyone must accept some kind of 'brute' inexplicable fact, why not keep one's metaphysics more elegant and just stop at the world itself? Moving one step further and stopping at God flies in the face of Occam's Razor and, worse yet, does so without any corresponding explanatory gains. ${ }^{20}$ This is just what Philo says to Cleanthes at the conclusion of Part IV of the Dialogues:

If I am still to remain in utter ignorance of causes and can absolutely give an explication of nothing, I shall never esteem it any advantage to shove off for a moment a difficulty which you acknowledge must immediately, in its full force, recur upon me. Naturalists, indeed, very justly explain particular effects by more general causes, though these general causes themselves should remain in the end totally inexplicable: but they never surely thought it satisfactory to explain a particular effect by a particular cause which was no more to be accounted for than the effect itself. An ideal system, arranged of itself, without a precedent design, is not a whit more explicable than a material one which attains its order in a like manner; nor is there any more difficulty in the latter supposition than in the former. ${ }^{21}$

Now, just as the order of the divine mind is claimed to explain the order of the world, in a parallel way the beauty of, and in, the divine mind is claimed to explain the beauty of the natural world. But, as we have seen, this merely raises a further question: viz., what explains the beauty of, and in, the divine mind? Thus it would seem that the argument from beauty can offer us no explanatory gains, since the divine beauty is at least as puzzling as worldly beauty is, if we imagine this divine beauty as a brute

${ }^{19}$ Cleanthes: '[Y] ou [viz., Philo] ask me what is the cause of this cause? I know not; I care not; that concerns not me. I have found a Deity; and here I stop my inquiry. Let those go farther who are wiser or more enterprising.' (Hume 1998: 32-33)

${ }^{20}$ Cf. Hume (1998: 36-37).

${ }^{21}$ Hume (1998: 33). 
fact that is beyond explanation. Indeed, the situation is arguably worse when the 'brute' inexplicable fact is divine beauty, since divine beauty would presumably greatly exceed worldly beauty, making it all-the-more in need of explanation. So, to summarize, moving (inferentially) beyond worldly beauty to divine beauty flies in the face of Occam's Razor, without corresponding explanatory gains, and may in fact give us an even more puzzling explanandum (viz., the glorious divine beauty itself). Can the defender of the argument from beauty solve this difficulty?

\section{WYNN'S REPLY TO PHILO \& A PHILONIAN COUNTER}

Among the defenders of the argument from beauty, at least one has explicitly noted the apparent problem for that argument posed by Philo's explanatory regress objection. ${ }^{22}$ Now, in the previous section I argued that it would seem that the argument from beauty offers us no explanatory gains, since the divine beauty is at least as puzzling as worldly beauty is, if we imagine this divine beauty as a brute fact that is beyond explanation. However, this is precisely what Wynn proposes to challenge. Wynn argues that Philo's objection can be met if 'God's beauty is to be explained by reference to God's own activity, so that it is after all explained, and not merely posited as a "brute fact" ${ }^{23}$ So, in this section I want to attempt to lay out Wynn's response to Philo's objection, and I want to try to explain why I think that Wynn's response is inadequate.

Wynn develops his response to the explanatory regress objection in Chapter 6 of his God and Goodness. ${ }^{24}$ Unfortunately Wynn's response to the objection is not articulated qua response to the objection, leaving the reader the task of trying to understand how the material in Chapter 6 responds to the objection. We can start by considering one unpromising way of understanding the (purported) divine self-expression found in natural beauty. Suppose that God's own beauty is somehow echoed or mirrored in natural beauty. Two problems immediately suggest themselves. First, how then does God's own beauty produce natural beauty? The painter of a beautiful painting need not be a beautiful painter: Ugly artists can make strikingly beautiful art. Second, if we imagine

${ }^{22}$ Wynn (1999). See pp. 13 and 22-23 where the explanatory regress is clearly stated.

${ }^{23}$ Wynn (1999: 23, my emphasis).

${ }^{24}$ I have confirmed this through personal (email) communication with Professor Wynn, who has assured me that his reply to the objection is contained in the material found in Chapter 6 of God and Goodness. 
some form of 'overflowing' of the divine beauty, of which natural beauty is the spillage (as it were), this leaves that same divine beauty as an utterly 'brute' fact of the sort Wynn is concerned to avoid. After all, what would then explain the divine beauty?

Thus, what we are seeking (on Wynn's behalf, with help from Chapter 6) is an understanding of natural beauty that makes it more an expression of (rather than an imitative overflowing of) the Designer. Moreover, if we can connect natural beauty to divine activity, as Wynn seeks to, then perhaps we can make some progress toward understanding how natural beauty can be explained by something (divine activity) that is not itself in need of further explanation, without being problematically 'brute'.

And so we find Wynn arguing that the integrated beauty of the world itself is a product of the divine mind. Thus, worldly beauty reflects and points to divine beauty: ' $\mathrm{T}]$ he many diverse forms of existence which we encounter in the cosmos, when taken together, provide our clearest image of God.25 For it was the divine mind which designed and brought about the 'radiantly attractive synthesis' of things that is evident in creation. ${ }^{26}$ So, again, worldly beauty reflects and points toward divine beauty. But this divine beauty, says Wynn, 'is to be explained by reference to God's own activity', namely God's synthetic or integrative work in producing a 'radiantly attractive' creation. ${ }^{27}$

Focusing the discussion on divine activity, then, seems to be Wynn's approach, and he spends most of Chapter 6 articulating and evaluating several competitor accounts of divine activity. ${ }^{28}$ It seems to me, however, that nothing in any of these several accounts - including the account outlined roughly in the previous paragraph - offers us any hope of resolving the explanatory regress objection, so I am prepared to stipulate that Wynn can consider any of those accounts as established (for the sake of argument). Still, I believe the objection remains unanswered. Here's why. If God's activity means (among other things) designing things, then this reply collapses back into Philo's original objection to the standard design argument: after all, artists are indeed 'designers' in a broad sense. So even if God's beauty isn't just a fact about Him, but rather a fact about

${ }^{25}$ Wynn (1999: 153).

${ }^{26}$ For the quoted phrase, see, e.g., (1999: 155, 156, and 158).

${ }^{27}$ For the quoted phrase, see (1999: 23).

${ }^{28}$ For further details, see Chapter 6 of Wynn (1999), perhaps especially pp. 155-156 (which Wynn specifically emphasized in our correspondence). 
His (designing) activities - achieving that 'radiantly attractive synthesis' of created things - still we can wonder how such complex abilities came to reside in God. If at this point we are told this is simply 'brute' - it's the nature of God - then Wynn has failed to meet his argumentative burden: On Wynn's account, God's beauty - which is rooted in His extraordinary design skills - is ultimately as 'brute' as the bruteness of those design skills themselves. Order and beauty in the world, we are being told, require some explanation, but order and beauty in the divine mind can be 'brute' facts not admitting of further explanation. ${ }^{29}$ Wynn's proposal had been to avoid such bruteness, but once the details of his approach are made clear, it is likewise clear that his proposal leads us right back to Philo's original complaint.

Collecting these points together, it therefore seems that we can either think of natural beauty in relation to God's own beauty (of which the former is an imitative overflowing), or else we can think of natural beauty as the fulfilment of a project of divine artistry, conceived and executed via various divine activities. But the first interpretation - imitative overflowing - invites the explanatory regress (i.e., so who made God beautiful?) or else collapses into an assertion of the bruteness of God's beauty (to which we might reply with an equally justified assertion of the bruteness of natural beauty). And the second interpretation - a project of divine artistry - merely highlights the connections between the argument from beauty and the standard design arguments by treating natural beauty (like natural orderliness) as the expression of the activities of the divine mind. But if so then the second interpretation (which is Wynn's view, as far as I can discern it) actually takes us back to Philo's original worry, to wit: We are trying to explain 'a particular effect by a particular cause which was no more to be accounted for than the effect itself. An ideal system, arranged of itself, without a precedent design, is not a whit more explicable than a material one which attains its order in a like manner; nor is there any more difficulty in the latter supposition than in the former. ${ }^{30}$ Or, as Wynn himself states the objection early in his book, 'the argument lacks any explanatory force because it postulates a further set of facts as much in need of explanation as those which it purports to explain. ${ }^{31}$

\footnotetext{
${ }^{29} \mathrm{Cf}$. again the lines from Cleanthes quoted in note 19, above.

${ }^{30}$ Hume (1998: 33).

${ }^{31}$ Wynn (1999: 13).
} 
To avoid a vicious explanatory regress perhaps all disputants must accept some 'brute' facts. Perhaps we must accept certain 'brute' facts about beautiful things as well. But choosing to accept the bruteness of the beauty of, and in, the divine mind is no improvement over accepting the bruteness of natural beauty. Thus, the attempt to argue from natural beauty to the likely existence of a divine Artist fails. Gloria in excelsis Philo. ${ }^{32}$

\section{BIBLIOGRAPHY}

Cooper, John, ed. 1997. Plato: Complete Works (Indianapolis: Hackett Publishing Company)

Dawkins, Richard. 2008. The God Delusion (Boston: Mariner Books)

Forrest, Peter. 1996. God Without the Supernatural (Ithaca: Cornell University Press)

Hume, David. 1998. Dialogues Concerning Natural Religion. 2nd ed. Ed. by Richard H. Popkin (Indianapolis: Hackett Publishing Company)

Kellert, Stephen R. \& Edward O. Wilson, eds. 1993. The Biophilia Hypothesis (Washington, D.C.: Island Press)

Locke, John. 1975. An Essay Concerning Human Understanding, ed. by Peter H. Nidditch (Oxford: Clarendon Press)

Plantinga, Alvin. 2000. Warranted Christian Belief(New York: Oxford University Press)

Plantinga, Alvin. 1983. 'Reason and Belief in God', in Alvin Plantinga \& Nicholas Wolterstorff (1983: 16-93)

Plantinga, Alvin. 1981. 'Is Belief in God Properly Basic?', Noûs, 15: 41-51

Plantinga, Alvin \& Nicholas Wolterstorff, eds. 1983. Faith and Rationality (Notre Dame: University of Notre Dame Press)

Swinburne, Richard. 2004. The Existence of God, 2nd ed. (Oxford: Clarendon Press)

Tennant, F. R. 1930. Philosophical Theology, 2 vols. (Cambridge: Cambridge University Press)

Ulrich, Roger S. 1993. 'Biophilia, Biophobia, and Natural Landscapes', in Kellert and Wilson (1993: 73-172)

Wilson, E. O. 1984. Biophilia (Cambridge: Harvard University Press)

Wynn, Mark. 1999. God and Goodness (London: Routledge)

${ }^{32}$ For discussion and comments which have improved this paper I would like to thank Crisler Torrence, Mark Wynn, and the participants at the 2012 Central Division meeting of the Society of Christian Philosophers. 